\title{
Analysis of 3'UTR of Prnp Gene in Mammals: Possible Role of Target Sequences of miRNA for TSE Sensitivity in Bovidae and Cervidae
}

\author{
Daniel Petit, Jean-Michel Petit and François Gallet \\ UGMA, UMR 1061 INRA/University of Limoges
}

France

\section{Introduction}

Transmissible spongiform encephalopathies (TSEs) or prion diseases are neurodegenerative diseases with an inexorably fatal outcome. They affect both human and other mammals, and are especially frequently found in Bovidae and Cervidae families (Aguzzi \& Sigurdson, 2004). In the first family, sheep and goats can spontaneously develop the prion disease or scrapie (Grenn et al., 2008), whereas cattle only develop a disease, known as Bovine Spongiform Encephalopathy (BSE), after a contact with the infectious prion protein (Ducrot et al., 2008). In the second family, the chronic wasting disease (CWD) has been described in mule deer and elk. Besides these two Ruminant families, TSE was also retrieved in Carnivora, as Felidae (feline spongiform encephalopathy) and Mustelidae (transmissible mink encephalopathy) (Miller et al., 2008; Sigurdson \& Miller, 2003). All these diseases are characterized by the accumulation of PrPSc, the abnormally folded isoform of the cellular prion protein (PrPC) in the brain (Prusiner 1998; Norrby 2011).

The cellular prion protein is a glycosylphosphatidylinositol anchored glycoprotein of 256 amino acids in sheep (Bovidae, subfamily Caprinae) and Cervidae. The N-ter of the protein is mainly unstructured while the C-terminal domain is globular. The C-ter domain is highly structured and is stabilized by an intramolecular disulfide bound. It contains three $\alpha$-helices and a short $\beta$-sheet. TSE is a conformational disease, where change from PrPC to PrPSc involves an increase in $\beta$-sheet content from $3 \%$ to $40 \%$, and a decrease in $\alpha$-helical structure from $40 \%$ to $30 \%$ that modify irreversibly the protein folding (Cohen et al., 1998; Smirnovas et al., 2009).

In a previous work, we showed that the ARQ/ARQ genotype is rather sensitive to the TSE in sheep and goat but protective in pig and rabbit, known as resistant species [Martin et al., 2009]. Otherwise, several studies point out that the expression level of the prion gene could modulate the onset of TSE, particularly in cattle (Sander et al., 2004-2006; Haase et al., 2007). The involvement of the $5^{\prime}$ promoter region has been investigated in sheep (Saunders et al., 2009) and cattle (Xue et al., 2008) and it appears that polymorphism in this region could induce different responses to scrapie (Marcos-Carcavilla et al., 2008) and BSE (Brunelle et al., 2008). The analysis of a $23 \mathrm{pb}$ insertion/deletion polymorphism in German and Swiss breed cattle revealed that the deletion is associated to a higher expression level, more frequently 
found in cattle affected with classical BSE. Moreover, in vitro studies showed that the possibility to infect neurosphere cultures with scrapie prion is linked to an over-expression of PrPC (Giri et al., 2006). Although the determinism of prion disease is multifactorial (prion strain and prion protein sequence, see Doherr, 2003), it seems that a high expression of PrPC gene is necessary (Krejciova et al., 2011).

In numerous organisms, post-transcriptional gene regulation involves small (around 18-25 nucleotides long) non-coding RNA molecules, the microRNAs (miRNAs). They recognise specific target sequences in the 3'UTR of some transcripts, mediating their silencing (Fabian et al., 2010) by inducing their degradation or by inhibiting their translation. According to the accuracy of the complementarity between both sequences, each miRNA can regulate up to hundreds of genes. Using microarrays, Saba et al. (2008) evidenced 15 miRNAs, potentially controlling the transcript amount of more than 100 genes. These micro-RNAs are deregulated in the brain of scrapie affected mouse.

In their comparative analysis of Prnp organization in human, mouse and sheep, Lee et al. (1998) showed the high conservation of the 3'-UTR regions and suggested their role in mRNA stability. Moreover, they evidenced insertions of transposable elements in the sheep gene. In their more recent work, Premzl and Gamulin (2007) could easily align the part close to the poly-adenylation signal in a wide range of mammals. Taken together, these data suggest that alignments of mammalian $3^{\prime}$ UTRs contain reliable information. The regulatory sequences borne by the $3^{\prime}$-UTR are involved in mRNA processing, transport, stability, and translation. As the 3'-UTRs harbor recognition sites for diverse RNA-binding proteins that regulate gene expression as well as active microRNA target sites, our strategy was to compare the 3'UTR of the Prnp gene, from the sequence terminus codon to the polyadenylation signal in different Mammal lineages. We expect to find in the most frequently families affected by TSE, i.e., Bovidae and Cervidae, oddities in their potential miRNA targets. Three types of results are predicted to be obtained. In the first type, based on the miRNA-related gene silencing, we predict that Bovidae and Cervidae families lack some targets widely present in other Mammals. In the second type, we predict that target sequences are present in DNA from most mammalian lineages, including the both critical families, but a loss of corresponding miRNA may occur. The last type, although more unlikely, would be to detect targets only harboured by Bovidae and Cervidae, which would lead to the activation of gene expression, as shown by Vasudevan et al. (2007) in a model of cellular stress. In brief, we search for potential targets that could affect repression mechanisms of Prnp gene expression, and thus enhance the sensitivity of Bovidae and Cervidae to the disease.

\section{Material and methods}

A Blast search of 3'UTR sequences in traces (Whole Genome Shotgun) of NCBI genome database was undertaken. We restricted the species sampling to 2 to 3 species for main division within Eutherians, and the outgroup was constituted by 2 Marsupials (Macropus eugenii and Didelphis domestica). The alignment of sequences was performed with Dialign software (Morgenstern, 2004), and then manually edited. The table 1 gathers the 27 analyzed sequences and their accession numbers. The repeat elements were identified with RepeatMasker site (http://www.repeatmasker.org/cgi-bin/WEBRepeatMasker). The target 
sequences of mi-RNAs were detected with mirBase (www.mirbase.org/), following the papers of Griffiths-Jones (2004), Griffiths-Jones et al. (2006 and 2008), and Kozomara \& Griffiths-Jones (2011).

\begin{tabular}{ll}
\hline Species names & Access numbers in NCBI \\
\hline Bos taurus & NM_181015 \\
Canis familiaris & NC_006606.2 \\
Cervus elaphus & EU032284 \\
Equus caballus & AAWR02026367.1 \\
Felis catus & ACBE01091825.1 \\
Homo sapiens & NC_000020.10, U29185 \\
Lama pacos & ABRR01260217 \\
Loxodonta africana & AAGU03041236.1 \\
Macropus eugenii & ABQO010016931.1 \\
Monodelphis domestica & AAFR03004045.1 \\
Mus musculus & NM_011170, U29186 \\
Mustella putorius & AEYP01079589.1 \\
Myodes glareolus & EF455012 \\
Myotis lucifugus & AAPE02032418.1 \\
Ochotona princeps & AAYZ01152834.1 \\
Odocoileus hemionus & AY330343 \\
Oryctolagus cuniculus & NW_003159242.1 \\
Ovis aries & NM_00100948.1, U67922 \\
Procavia capensis & ABRQ01131540.1 \\
Pteropus vampyrus & ABRP01225173.1 \\
Rattus norvegicus & NC_005102.2 \\
Saimiri sciureus & ti|1176383476 \\
Sorex araneus & AALT01429291.1 \\
Spermophilus tridecemlineatus & AAQQ01175405.1 \\
Sus scrofa & NM_001008687 \\
Tarsius syrichta & ABRT010290102.1 \\
Tursiops truncatus & ABRN01336586.1 \\
\hline
\end{tabular}

Table 1. List of mammalian studied species

In order to visualise the most conservative sites of the $3^{\prime} \mathrm{UTR}$, we used the method developed in Petit et al. (2006) and Martin et al. (2009). Briefly, the alignment of sequences, cleaned from insertions, was treated by Parsimony program of Phylip package vers. 3.69 (Felsenstein, 2004), to export the number of changes site by site. For each site, this number was divided by the number of sequences, allowing drawing the profile of site change rates.

\section{Results}

\subsection{Position of insertions and deletions}

The length of the 3'UTR region is highly variable as the murine sequence comprises about $1250 \mathrm{pb}$ whereas the bovine one is more than $3500 \mathrm{pb}$ long and possesses two potential polyadenylation signals that are separated by about $1300 \mathrm{bp}$. Such a result is also observed in sheep and mule deer. The difference is mainly explained by a series of transposable 
elements (SINE/RTE-BovB of about 380 pb length, SINE/BovA about 160 bp length and DNA/TcMar-Mariner with at least $1220 \mathrm{bp}$ ). All are inserted in the $3^{\prime}$ end of the bovine sequence, and also shared by sheep, red deer, and mule deer (Fig. 1). A striking common organization is indicative of events that occurred in the ancestors of Bovidae and Cervidae. In spite of extensive searches, these elements were not retrieved in the other studied mammals. Upstream the transposable elements, we observe a good overall conservation of the sequences, allowing to clearly evidence insertion and deletion events in some species.
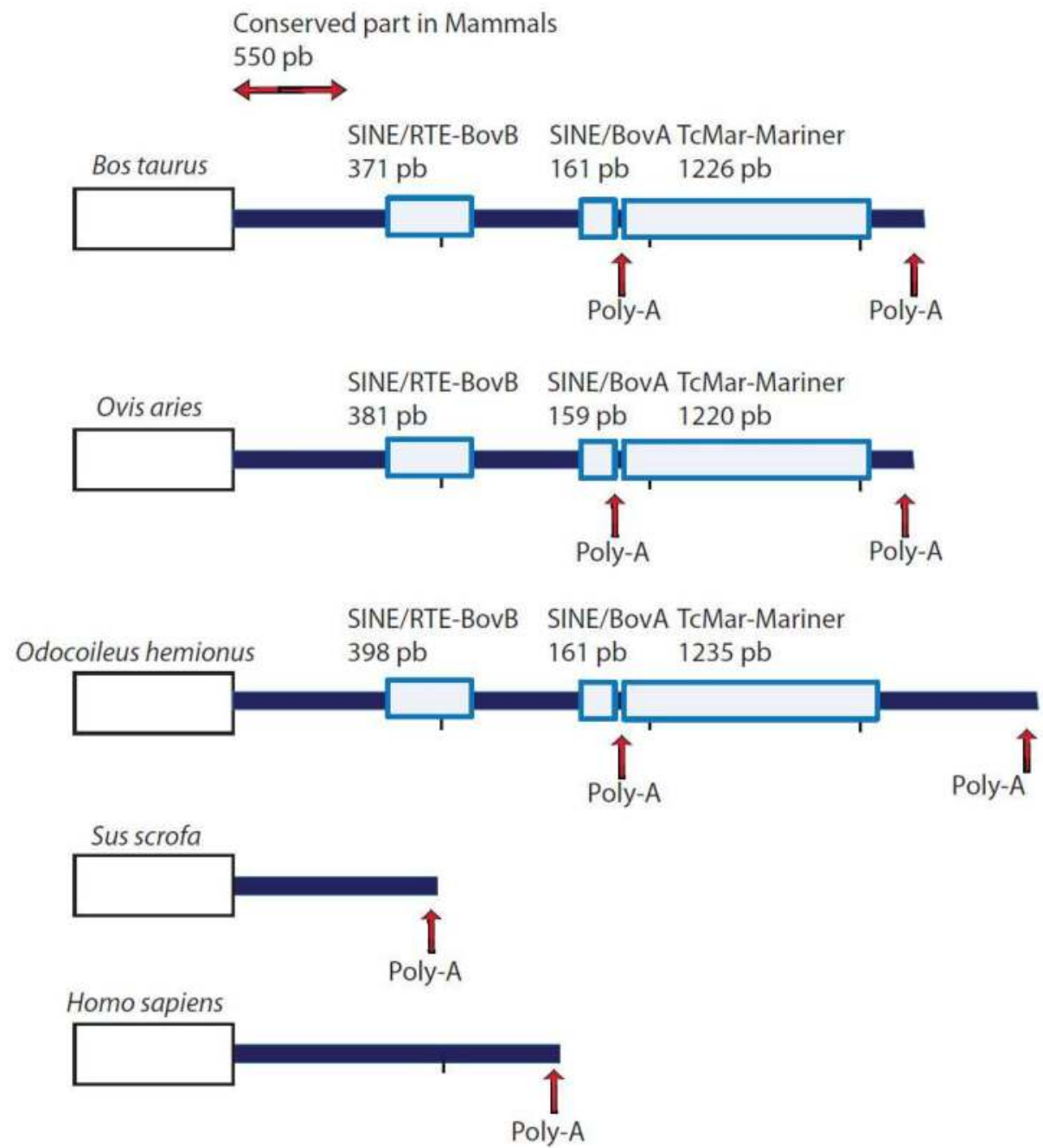

Fig. 1. Organization of the Prnp 3'UTR in several Mammals. The coding sequence of the gene is boxed in thin black. The inserted elements are boxed in thick blue. There are two poly-adenylation signals (Poly-A) in Bovidae-Cervidae, and only one in human and porcine. Short vertical lines are drawn every $1000 \mathrm{pb}$. 


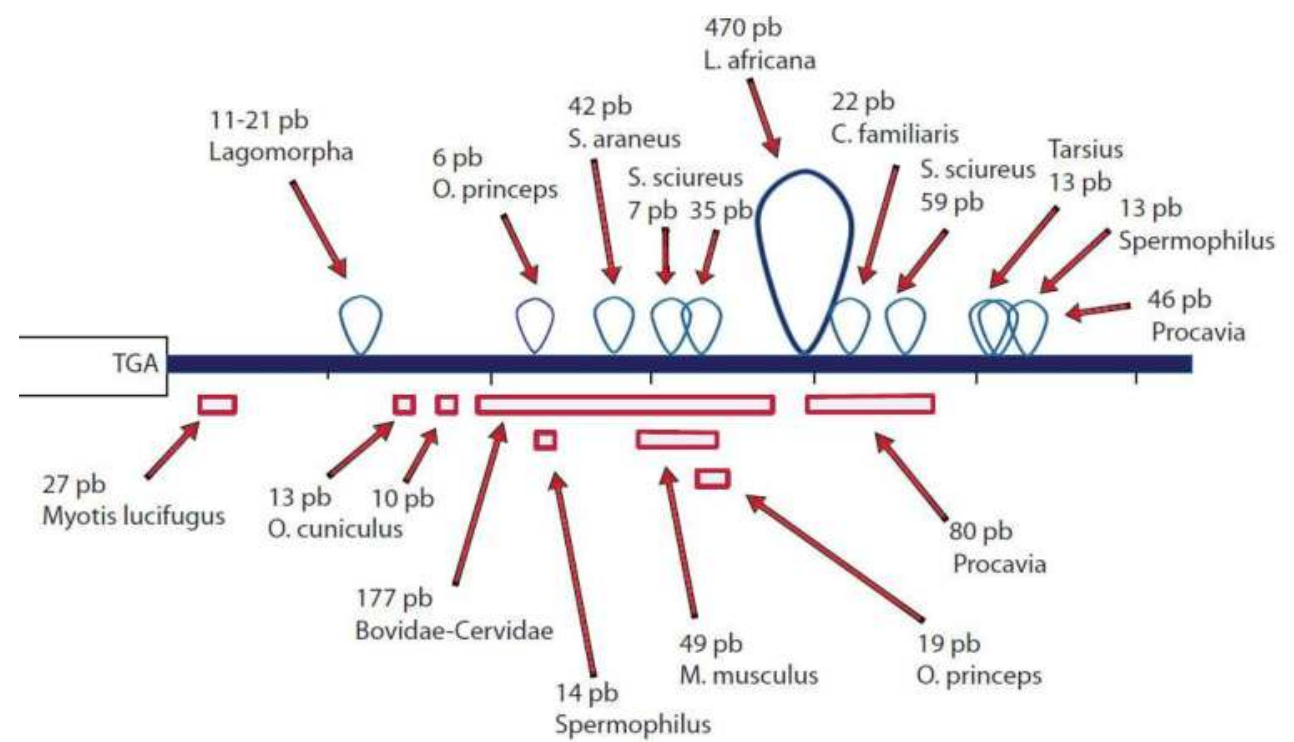

Fig. 2. Position of insertions (loops above the thick blue line) and deletions (wide red rectangles below) in the $550 \mathrm{pb}$ conserved part of Eutherians. The hypothetical ancestral sequence for Eutherians was taken as reference. Short vertical lines are drawn every $100 \mathrm{pb}$.

The most interesting features are a $177 \mathrm{pb}$ long deletion specific to Cervidae-Bovidae, and a $470 \mathrm{pb}$ long insertion in African Elephant. No indel particular to human could be recorded.

\subsection{Profile of site change rates along the 3'UTR}

The most conserved sites are between positions 70 and 115 downstream the stop codon. In the part corresponding to the deletion shared by Bovidae and Cervidae, we observed little variations in Eutherians. From the 550th position on, due to a lowest identity between species, the sequences cannot be significantly aligned (fig. 3).

\subsection{Position of potentially target sites of miRNAs}

We focused on 3 regions: (i) between the stop codon and the last nucleotide before the large deletion affecting Bovidae-Cervidae (proximal region), (ii) inside this large deletion, and (iii) in the transposable elements shared by Bovidae-Cervidae.

The table 2 gathers the target sites present in more than one species, in the region proximal to codon stop. It should be noted that several potential targets are overlapping (fig. 4-5). In two cases, the distribution of target is identical in the studied mammals and they were considered as identical (Mir-569-155 on one hand and Mir-3918-509 on the other). In contrast, the presence of other overlapping targets varies among mammals (Mir-3102, 376, 3918/509, 519 and 3432). Several targets are shared by only Bovidae-Cervidae species (Mir569/155, 376, 15b), or Bovidae-Cervidae and other mammals (Mir-3102 with M. musculus and S. scrofa, Mir-3918/509 with H. sapiens, M. putorius, and O. princeps, Mir-519 with C 
familiaris, M. putorius or S. scrofa). Mir-3432 and Mir-140 have targets shared by C. familiaris and several species, including $H$. sapiens, M. musculus or S. scrofa. In summary, the widest distribution of a given target concerns Mir-3918/509, but not any target is common to all mammals excluding the Bovidae-Cervidae. If the region encompassing targets to Mir3918/509-519 is taken as a whole, it should be noted that most mammals (except murine) share this region. Otherwise, no target was found to be shared by F. catus and non-Felidae mammals, or by E. caballus and non-Equidae mammals. In contrast, there are several targets shared by only Bovidae-Cervidae.

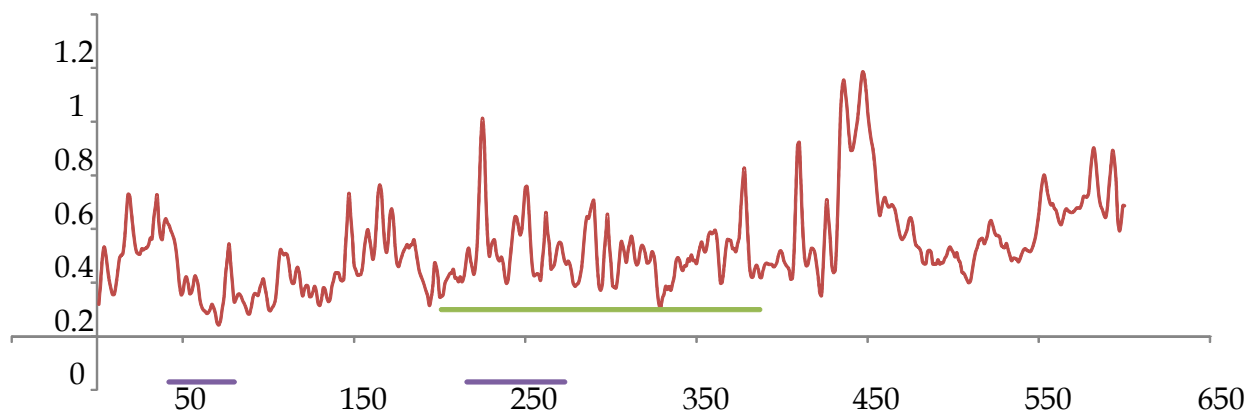

Fig. 3. Profile of site change rates within a $600 \mathrm{pb}$ long segment downstream the stop codon. The numbers in abscissa correspond to the hypothetical ancestral sequence for Eutherians. The violet thick lines correspond to the position of putative targets for Mir-509 group and Mir-369 group. The green thick line corresponds to the position of the large deletion in Bovidae-Cervidae.
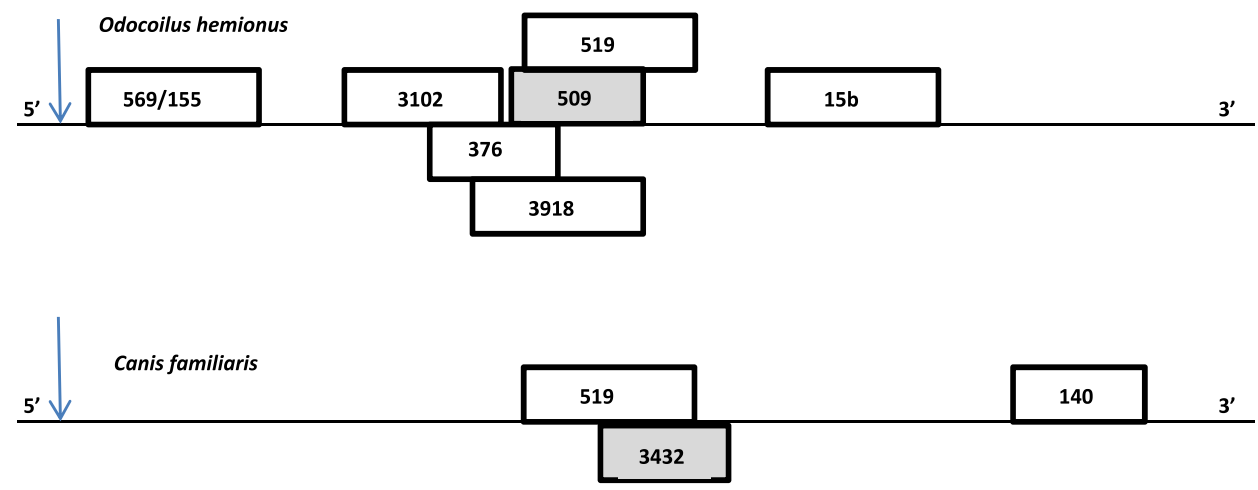

Fig. 4. Position of the putative targets for Mirs in the proximal region. The arrows indicate stop codon position. The grey boxes correspond to targets present in human. 

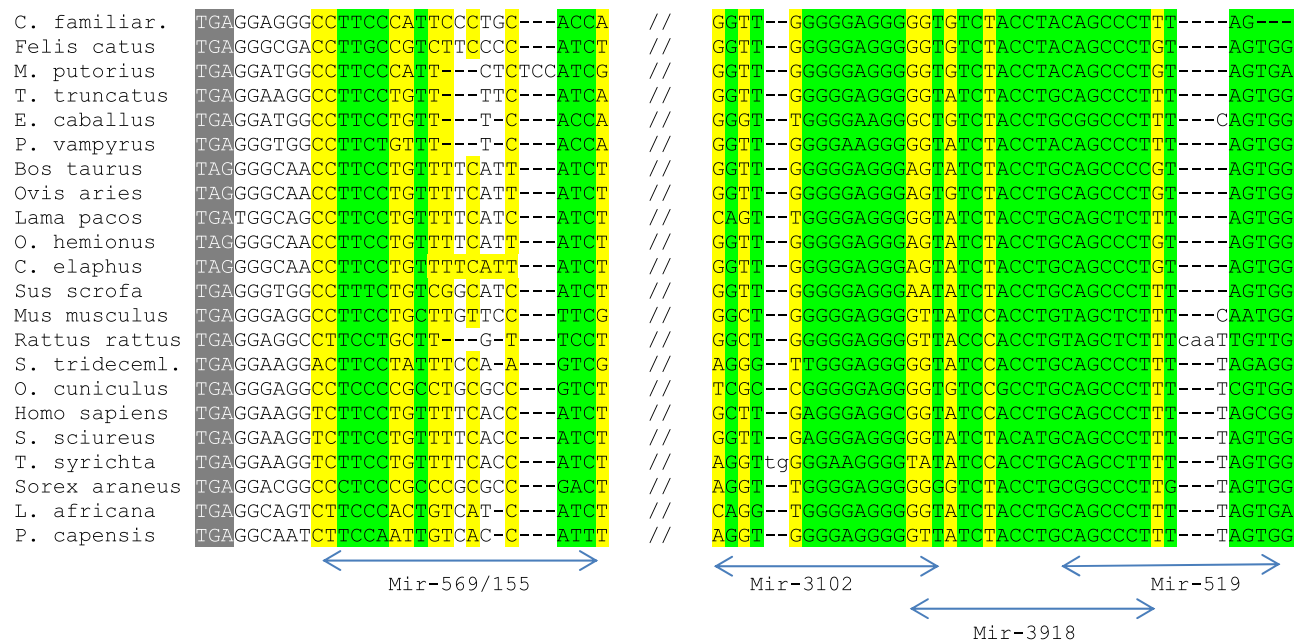

Fig. 5. Alignment of targets for Mirs in the proximal region of stop codon in mammals. Grey background: stop codon, green background: conservation in $\geq 75 \%$ sequences; yellow background: conservation in $\geq 50 \%$ sequences.

\begin{tabular}{|c|c|c|c|c|c|c|c|c|c|c|}
\hline $\begin{array}{c}\text { Mir } \\
\text { name }\end{array}$ & $\begin{array}{c}\text { Bos } \\
\text { taurus }\end{array}$ & $\begin{array}{c}\text { Canis } \\
\text { familiaris }\end{array}$ & $\begin{array}{c}\text { Cervus } \\
\text { elaphus }\end{array}$ & $\begin{array}{c}\text { Homo } \\
\text { sapiens }\end{array}$ & $\begin{array}{c}\text { Mus } \\
\text { musculus }\end{array}$ & $\begin{array}{c}\text { Mustela } \\
\text { putorius }\end{array}$ & $\begin{array}{c}\text { Ochotona } \\
\text { princeps }\end{array}$ & $\begin{array}{l}\text { Odocoilus } \\
\text { hemionus }\end{array}$ & $\begin{array}{c}\text { Ovis } \\
\text { aries }\end{array}$ & $\begin{array}{c}\text { Sus } \\
\text { scrofa }\end{array}$ \\
\hline $569 / 155$ & $\mathrm{X}$ & & $\mathrm{X}$ & & & & & $\mathrm{X}$ & $\mathrm{X}$ & \\
\hline 3102 & $\mathrm{X}$ & & $\mathrm{X}$ & & $\mathrm{X}$ & & & $\mathrm{X}$ & $\mathrm{X}$ & $\mathrm{X}$ \\
\hline 376 & $\mathrm{X}$ & & $\mathrm{X}$ & & & & & $\mathrm{X}$ & & \\
\hline $\begin{array}{c}3918 / 50 \\
9\end{array}$ & $\mathrm{X}$ & & $\mathrm{X}$ & $\mathrm{X}$ & & $\mathrm{X}$ & $\mathrm{X}$ & $\mathrm{X}$ & $\mathrm{X}$ & \\
\hline $\mathbf{5 1 9}$ & & $\mathrm{X}$ & $\mathrm{X}$ & & & $\mathrm{X}$ & & $\mathrm{X}$ & $\mathrm{X}$ & $\mathrm{X}$ \\
\hline 3432 & & $\mathrm{X}$ & & $\mathrm{X}$ & & & & & & $\mathrm{X}$ \\
\hline $\mathbf{1 5 b}$ & & & $\mathrm{X}$ & & & & & $\mathrm{X}$ & $\mathrm{X}$ & \\
\hline 140 & & $\mathrm{X}$ & & & $\mathrm{X}$ & & & & & \\
\hline
\end{tabular}

Table 2. Micro RNAs targets common to several species between the stop codon and the large deletion.

Within the sequence corresponding to the large deletion region, several targets (Mir-4763, 1587, 744, 15b, and 369) are overlapping (fig. 6-7). In two couples of targets (Mir 569/155 and Mir-3918/509), the distributions in mammals are identical and each couple was considered as single. The remaining overlapping targets have their own distribution within mammals, and they were considered separately (table 3). It appears that the number of putative targets common to at least 2 species varies among the different mammals. There is none in M. musculus, but four in E. caballus and even six in F. catus. There is no target common to all orders of mammals, but two are shared by at least four groups: Mir-4763 is 
common to E. caballus, F. catus, L. pacos and S. scrofa, and Mir-15B/369 to E. caballus, H. sapiens, F. catus, and S. scrofa.
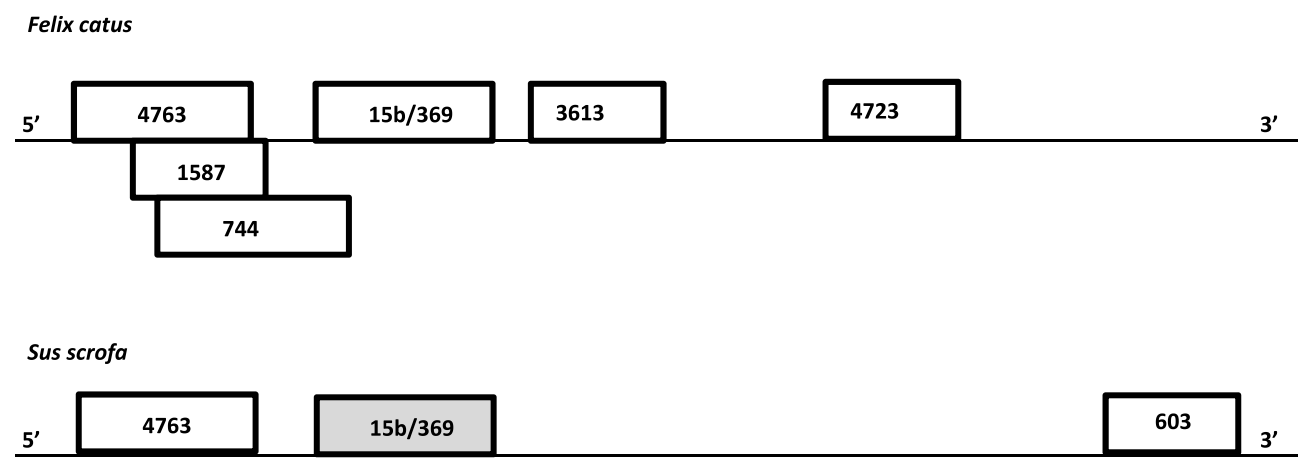

Fig. 6. Position of putative targets within the large deletion common to Bovidae-Cervidae. The grey box corresponds to the target present in human.

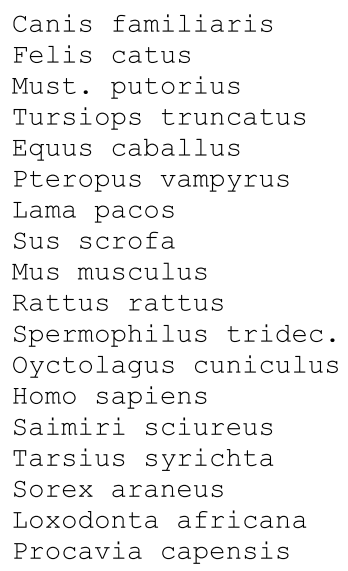

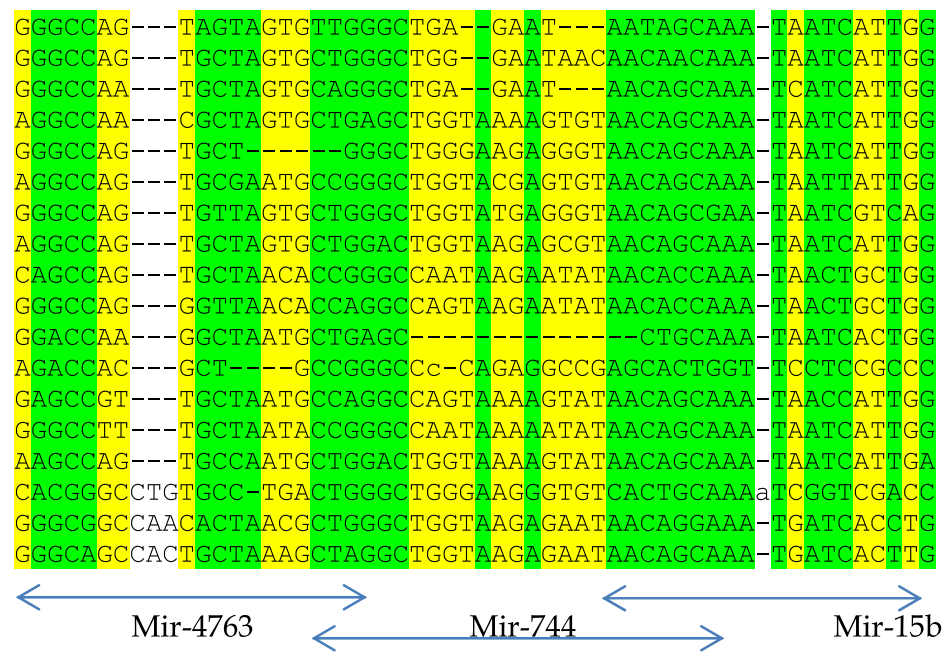

Fig. 7. Alignment of overlapping target sequences in the region of the large deletion common to Bovidae-Cervidae. Green background: conservation in $\geq 75 \%$ sequences; yellow background: conservation in $\geq 50 \%$ sequences.

Bovidae and Cervidae are the only species in which transposable elements are present in the transcript of Prnp. The poly-adenylation site common with other mammals is situated downstream from Mariner element. However, there is an extra potential poly-adenylation site, downstream to the SINE/BovA. Few targets for Mirs are present in these regions and common to B. taurus, O. aries and O. hemionus (Table 4). 


\begin{tabular}{|c|c|c|c|c|c|c|c|c|}
\hline Mir name & $\begin{array}{c}\text { Canis } \\
\text { familiaris }\end{array}$ & $\begin{array}{c}\text { Equus } \\
\text { caballus }\end{array}$ & $\begin{array}{c}\text { Homo } \\
\text { sapiens }\end{array}$ & $\begin{array}{c}\text { Felix } \\
\text { catus }\end{array}$ & $\begin{array}{c}\text { Lama } \\
\text { pacos }\end{array}$ & $\begin{array}{c}\text { Mustela } \\
\text { putorius }\end{array}$ & $\begin{array}{c}\text { Myodes } \\
\text { glareolus }\end{array}$ & $\begin{array}{c}\text { Sus } \\
\text { scrofa }\end{array}$ \\
\hline 4763 & & $\mathrm{X}$ & & $\mathrm{X}$ & $\mathrm{X}$ & & & $\mathrm{X}$ \\
\hline 1587 & & $\mathrm{X}$ & & $\mathrm{X}$ & & & & \\
\hline 744 & & & & $\mathrm{X}$ & & $\mathrm{X}$ & $\mathrm{X}$ & \\
\hline $15 \mathrm{~B} / 369$ & & $\mathrm{X}$ & $\mathrm{X}$ & $\mathrm{X}$ & & & & $\mathrm{X}$ \\
\hline 3613 & $\mathrm{X}$ & $\mathrm{X}$ & & $\mathrm{X}$ & & & & \\
\hline 603 & & & & & $\mathrm{X}$ & & & $\mathrm{X}$ \\
\hline 4723 & $\mathrm{X}$ & & & $\mathrm{X}$ & & & & \\
\hline
\end{tabular}

Table 3. Micro RNAs targets common to several species in the large deletion region

\begin{tabular}{|c|c|}
\hline Transposable elements & miRNAs \\
\hline \multirow{2}{*}{ SINE/RTE-BovB } & miR-4311 \\
\hline \multirow{2}{*}{ SINE/BovA } & miR-137 \\
\cline { 2 - 2 } & miR-596 \\
\cline { 2 - 2 } & miR-2277-3p \\
\hline \multirow{2}{*}{ TcMar-Mariner } & miR-2284d \\
\cline { 2 - 2 } & miR-701 \\
\cline { 2 - 2 } & miR-3143 \\
\cline { 2 - 2 } & miR-2294 \\
\hline
\end{tabular}

Table 4. Putative targets for Mirs, common to B. taurus, O. aries and O. hemionus.

\section{Discussion}

The most interesting feature in the comparative analysis of $3^{\prime} \mathrm{UTR}$ region of mammalian Prnp genes is the occurrence of 2 events common to Bovidae and Cervidae, i.e., a 177 pblong deletion and 3 insertions of transposable elements. These insertions were previously described in sheep by Lee et al. (1998), but not in Cervidae. To simplify the discussion, the large deletion common to Bovidae-Cervidae will be abbreviated as LDCBC in the following. The mammalian distribution of insertions and LDCBC fit with the phylogeny within Artiodactyla, since Bovidae and Cervidae were shown to be sister families by Kuznetsova et al. (2005) from $12 S$ and $16 S$ rRNA analyses. In contrast, the more basally genera Lama (Camelidae), Sus (Suidae) and Tursiops (Delphinidae) within Cetartiodactyla do not possess the LDCBC and the 3 insertions. Unfortunately, none studied species harboured either the LDCBC or the 3 insertions. The sequencing of Giraffa camelopardalis could bring an 
interesting issue, given its intermediary position between Bovidae-Cervidae group and the Camelidae. Consequently, it is not possible to assign a specific role of the LDCBC and or of the 3 insertions to the stability of Prnp RNA. Their potential influence will be assessed independently.

As explained in introduction, several types of potential target sites of micro-RNAs are to be explored according to their position relatively to the LDCBC: (i) between the stop codon and the LDCBC (all Mammals), (ii) in the sequence corresponding to the LDCBC (all Mammals except Bovidae-Cervidae), and (iii) in the inserted elements particular to Bovidae-Cervidae. Generally, miRNAs inhibit protein synthesis either by the repression of the translation and/or by the activation of the deadenylation leading to the degradation of the targeting mRNA (Eulalio et al., 2008; Chekulaeva \& Filipowicz, 2009). Multiples sites, either for the same or different miRNAs, are usually required for a more effective repression, and they tend to act cooperatively when they are close to each other (Doench et al., 2004; Grimson et al., 2007). As most microRNA play a role in repression, a special attention will be brought to targets present in most mammals but absent in Bovidae-Cervidae. However, targets restricted to Bovidae-Cervidae could have significance through an activating role in stability of transcript (Vasudevan et al., 2007).

In the sequence comprised between stop codon and LDCBC, the most spread target within mammals corresponds the group Mir-3918/509-519. According to fig. 3, this target is situated in one of the most conservative regions in 3'UTR of PRNP gene. Its possible involvement could be interpreted as the result of an under-expression of the corresponding Mirs in Bovidae-Cervidae, according to the second type mentioned in introduction section. It would be interesting to test experimentally this idea.

In the sequence corresponding to the large deletion common to Bovidae-Cervidae, two targets are interesting to consider, corresponding to Mir4763 and Mir-15B/369. According to literature, Mir15b belong to a small family of Mirs comprising also Mir15a, Mir16a, Mir16b, and Mir195 in Mammals. Interestingly, Mir15b as well as Mir15a have proved to be involved as repressing cancers in human. It has been shown an association between deletion of Mir15a gene, together with Mir16 in the same cluster in HSA chromosome 13q14, and pituitary tumors (Bottoni et al., 2005). The same authors showed that the expression level of these 2 Mirs is inversely correlated to the pituitary adenoma growth. Another study of Calin et al., 2002 showed that deletions in the same cluster of Mir 15b-Mir16 are associated to chronic lymphocytic leukemia. Similarly, a high expression level of Mir15b is linked to a low proliferation of hepatocellular carcinoma (Chung et al., 2010). As for Mir369, Williams et al. (2007) showed that members of family Mir-154 are especially expressed in mouse and human foetal, but not adult, lung.

The presence of transposable elements in the Prnp transcript of Bovidae and Cervidae is an interesting feature. It is unlikely that they contribute to the stability of mRNA, as no publications support this view. However, these transposable elements contain putative targets for Mirs that confer new possibility of regulation, as shown in mammals (Smalheiser \& Torvik, 2005). These putative Mirs could play a role in the stability of Prnp gene. We could bring the same hypothesis to the targets of Mir-569/155, 376, 15b, present in the region proximal to stop codon. 
The sensitivity to TSE has certainly multiple origins according to mammals. For example, the 3'UTR sequence of M. putorius, known as sensitive (Miller et al., 2008), presents no indel in the first $600 \mathrm{pb}$. Interestingly, this species as well as Myodes glareolus, another sensitive species (Di Bari et al., 2008), lack both targets for Mir 4763 and 15B/369, in contrast to the species known as resistant..

The sensitivity of a given Mammal to TSE depends on many factors, as shown by the network analyses conducted during the development of the disease. But even if many genes have been proved to be involved, the expression level of Prnp gene plays a crucial role and many approaches still need to be explored such as miRNAs.

\section{Conclusion}

The 3'-UTR sequence of Prnp gene is well conserved with Eutherians, and especially in the first $600 \mathrm{pb}$ downstream to stop codon, suggesting a role in regulation of stability of the mRNA. In the 3'-UTR part of SPRN, a gene close to Prnp, Premzl \& Gamulin (2007) showed a target for Mir-34a shared by several orders of mammals. It is unlikely that such a unique target is present in the case of mammalian Prnp. Our analyses rather suggest an interaction between several targets which could modulate the stability of this transcript. The combination of acting Mirs could vary among mammals and the high sensitivity of Bovidae and Cervidae could be explained by the lack of several key targets.

\section{Acknowledgments}

We thank the Région Limousin for financial support.

\section{References}

Aguzzi, A \& Sigurdson, C (2004). Antiprion immunotherapy: to suppress or to stimulate? Nat. Rev. Immunol., 4(9), 725-736.

Bottoni, A, Piccin, D, Tagliati, F, Luchin, A, Zatelli, MC, \& degli Uberti, EC. (2005). miR-15a and miR-16-1 down-regulation in pituitary adenomas. J. Cell Physiol., 204(1), 280285.

Brunelle, BW, Greenlee, JJ, Seabury, CM, Brown, CE 2nd, \& Nicholson, EM. (2008). Frequencies of polymorphisms associated with BSE resistance differ significantly between Bos taurus, Bos indicus, and composite cattle. BMC Vet. Research, 4, 36-43.

Calin, GA, Dumitru, CD, Shimizu, M, Bichi, R, Zupo, S, Noch, E, Aldler, H, Rattan, S, Keating, M, Rai, K, Rassenti, L, Kipps, T, Negrini, M, Bullrich, F, \& Croce, CM. (2002). Frequent deletions and down-regulation of micro- RNA genes miR15 and miR16 at 13q14 in chronic lymphocytic leukemia. Proc Natl Acad Sci U.S.A., 99(24), 15524-15529.

Chekulaeva, M, \& Filipowicz, W. (2009) Mechanisms of miRNA-mediated posttranscriptional regulation in animal cells. Curr. Opin. Cell Biol., 21, 452-60.

Chung, GE, Yoon, JH, Myung, SJ, Lee, JH, Lee, SH, Lee, SM, Kim, SJ, Hwang, SY, Lee, HS, \& Kim, CY. (2010). High expression of microRNA-15b predicts a low risk of tumor 
recurrence following curative resection of hepatocellular carcinoma. Oncol. Rep., 23(1), 113-119.

Cohen, FE, \& Prusiner, SB. (1998). Pathologic conformations of prion proteins. Annu. Rev. Biochem., 67, 793-819.

Di Bari, MA, Chianini, F, Vaccari, G, Esposito, E, Conte, M, Eaton, SL, Hamilton, S, Finlayson, J, Steele, PJ, Dagleish, MP, Reid, HW, Bruce, M, Jeffrey, M, Agrimi, U, \& Nonno, R. (2008). The bank vole (Myodes glareolus) as a sensitive bioassay for sheep scrapie. J Gen Virol., 89(Pt 12), 2975-2985.

Doench, JG, \& Sharp, PA. (2004). Specificity of microRNA target selection in translational repression. Genes Dev. 18:504-11.

Doherr, MG. (2003). Bovine spongiform encephalopathy (BSE) infectious, contagious, zoonotic or production disease? Acta Vet Scand Suppl., 98, 33-42.

Ducrot, C, Arnold, M, de Koeijer, A, Heim, D, \& Calavas, D. (2008). Review on the epidemiology and dynamics of BSE epidemics. Vet. Research, 39(4), 15.

Eulalio, A, Huntzinger, E, Izaurralde, E. (2008) Getting to the root of miRNA-mediated gene silencing. Cell, 132, 9-14.

Grimson A, Farh KK, Johnston WK, Garrett-Engele P, Lim LP, Bartel DP. (2007). MicroRNA targeting specificity in mammals: determinants beyond seed pairing. Mol. Cell., 27, 91-105.

Fabian, RF, Sonenberg, N, \& Filipowitz, W, (2010). Regulation of mRNA translation and stability by microRNAs. Annu. Rev. Biochem., 79, 351-379.

Felsenstein, J. (2004). PHYLIP (Phylogeny Inference Package) version 3.6. Distributed by the author. Department of Genome Sciences, University of Washington, Seattle.

Giri, R.K, Young, R., Pitstick, R., DeArmond, S.J., Prusiner, S.B., \& Carlson, G.A. (2006). Prion infection of mouse neurospheres Proc Natl Acad Sci U.S.A, 103(10), 38753880.

Green KM, Browning SR, Seward TS, Jewell JE, Ross DL, Green MA, Williams ES, Hoover EA, \& Telling GC. (2008). The elk PRNP codon 132 polymorphism controls cervid and scrapie prion propagation. J. Gen. Virol., 89(2), 598-608.

Griffiths-Jones, S. (2004). The microRNA Registry. Nucleic Acids Research, 32, D109-D111.

Griffiths-Jones, S, Grocock, RJ, van Dongen, S, Bateman, A, \& Enright, AJ. (2006). miRBase: microRNA sequences, targets and gene nomenclature. Nucleic Acids Research, 34, D140-D144.

Griffiths-Jones, S, Saini, HK, van Dongen, S, \& Enright, AJ. (2008). miRBase: tools for microRNA genomics. Nucleic Acids Research 36, D154-D158

Groschup, MH, Lacroux, C, Buschmann, A, Lühken, G, Mathey, J, Eiden, M, Lugan, S, Hoffmann, C, Espinosa, JC, Baron, T, Torres, JM, Erhardt, G, \& Andreoletti, O. (2007). Classic scrapie in sheep with the ARR/ARR prion genotype in Germany and France. Emerg Infect Dis., 13(8), 1201-1207.

Haase, B, Doherr, MG, Seuberlich, T, et al. (2007). PRNP promoter polymorphisms are associated with BSE susceptibility in Swiss and German cattle. BMC Genetics, 8, 15.

Kozomara, A, \& Griffiths-Jones, S. (2011). miRBase: integrating microRNA annotation and deep-sequencing data. Nucleic Acids Research, 39, D152-D157

Krejciova, Z, Pells, S, Cancellotti, E, Freile, P, Bishop, M, Samuel, K, Barclay, GR, Ironside, JW, Manson, JC, Turner, ML, De Sousa, P, \& Head, MW. (2011). Human embryonic 
stem cells rapidly take up and then clear exogenous human and animal prions in vitro. J. Patholology, 223(5), 635-645.

Kuznetsova, M. V., Kholodova, M. V, \& Danilkin, A. A. (2005). Molecular Phylogeny of Deer (Cervidae: Artiodactyla). Russian Journal of Genetic; 41(7), 742-749.

Lee, I.Y., Westaway, D., Smit, A.F.A., Wang, K., Seto, J., Chen, L., Acharya, C., Ankener, M., Baskin, D., Cooper, C., Yao, H., Prusiner, S.B. \& Hood, L.E. (1998). Complete genomic sequence and analysis of the prion protein gene region from three mammalian species. Genome Res. 8 (10), 1022-1037.

Marcos-Carcavilla, A, Calvo, JH, González, C, Moazami-Goudarzi, K, Laurent, P, Bertaud, M, Hayes, H, Beattie, AE, Serrano, C, Lyahyai, J, Martín-Burriel, I, \& Serrano, M. (2008). Structural and functional analysis of the HSP90AA1 gene: distribution of polymorphisms among sheep with different responses to scrapie. Cell Stress Chaperones,13(1), 19-29.

Martin, R., Gallet, P.-F., Rocha, D., \& Petit, D. (2009). Polymorphism of the Prion Protein in Mammals: A Phylogenetic Approach. Recent Patents on DNA \& Gene Sequences, 3(1), 1-9.

Miller, MW, Swanson, HM, Wolfe, LL, Quartarone, FG, Huwer, SL, Southwick, CH, \& Lukacs, PM. (2008). Lions and prions and deer demise. PLoS One, 3(12), e4019.

Morgenstern, B. (2004). DIALIGN: Multiple DNA and Protein Sequence Alignment at BiBiServ. Nucleic Acids Research, 32, W33-W36.

Norrby, E. (2011). Prions and protein-folding diseases. J Intern Med., 270(1), 1-14.

Petit, D., Maftah, A., Julien, R., \& Petit, J.M. (2006). En bloc duplications, mutation rates and densities of amino acid changes clarify the evolution of vertebrate $\alpha 1,3 / 4$ fucosyltransferases. Journ. Molecular Evolution, 63(3), 353-364.

Premzl, M., \& Gamulin, V. (2007). Comparative genomic analysis of prion genes. BMC Genomics.; Jan 2;8:1.

Prusiner, SB. (1998). Prions. Proc Natl Acad Sci USA, 95, 13363-13383.

Saba, R, Goodman, CD, Huzarewich, RLCH, Robertson, C, \& Booth, SA. (2008). A miRNA Signature of Prion Induced Neurodegeneration. PLoS ONE, 3(11), e3652.

Sander, P, Hamann, H, Pfeiffer, I, et al. (2004). Analysis of sequence variability of the bovine prion protein gene (PrnP) in German cattle breeds. Neurogenetics, 5, 19-25.9

Sander, P, Hamann, H, ller, CDG, Kashkevich, K, Schiebel, K, \& Leeb, T. (2006). Bovine Prion protein gene (PrnP) promoter polymorphisms modulate PrnP expression and may be responsible for differences in bovine spongiform encephalopathy susceptibility. J Biol Chem., 280 (45), 37408-37414.

Saunders, GC, Cawthraw, S, Mountjoy, SJ, Tout AC, Sayers AR, Hope J, \& Windl O. (2009). Ovine PRNP untranslated region and promoter haplotype diversity. J Gen Virol., 90(Pt 5),1289-1293.

Sigurdson, CJ, \& Miller, MW. (2003). Other animal prion diseases. Br. Med Bull., 66, 199-212.

Smalheiser, NR, \& Torvik, VI. (2005). Mammalian microRNAs derived from genomic repeats. Trends Genet. (6),322-6.

Smirnovas, V, Kim, JI, Lu, X, Atarashi, R, Caughey, B, \& Surewicz, WK. (2009). Distinct structures of scrapie prion protein (PrPSc)-seeded versus spontaneous recombinant prion protein fibrils revealed by hydrogen/deuterium exchange. J. Biol. Chem., 284(36), 24233-24241. 
Vasudevan, S, Tong, Y, \& Steitz, JA. (2007). Switching from repression to activation: MicroRNAs can up-regulate translation. Science, 318(5858), 1931-1934.

Williams, AE, Moschos, SA, Perry, MM, Barnes, PJ, \& Lindsay, MA. (2007). Maternally imprinted microRNAs are differentially expressed during mouse and human lung development. Dev. Dyn., 236(2), 572-580.

Xue, G, Sakudo, A, Kim, CK, \& Onodera, T. (2008). Coordinate regulation of bovine prion protein gene promoter activity by two Sp1 binding site polymorphisms. Xue G, Sakudo A, Kim CK, Onodera T. Biochem Biophys Res. Commun., 372(4), 530-535. 


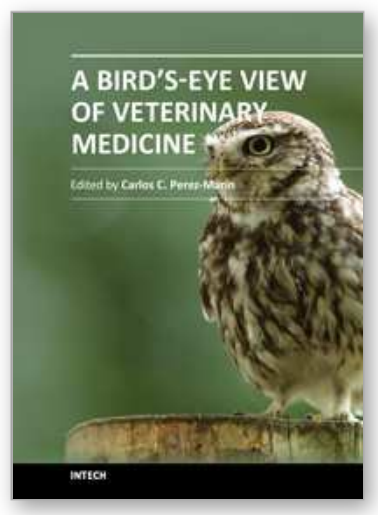

\author{
A Bird's-Eye View of Veterinary Medicine \\ Edited by Dr. Carlos C. Perez-Marin
}

ISBN 978-953-51-0031-7

Hard cover, 626 pages

Publisher InTech

Published online 22, February, 2012

Published in print edition February, 2012

Veterinary medicine is advancing at a very rapid pace, particularly given the breadth of the discipline. This book examines new developments covering a wide range of issues from health and welfare in livestock, pets, and wild animals to public health supervision and biomedical research. As well as containing reviews offering fresh insight into specific issues, this book includes a selection of scientific articles which help to chart the advance of this science. The book is divided into several sections. The opening chapters cover the veterinary profession and veterinary science in general, while later chapters look at specific aspects of applied veterinary medicine in pets and in livestock. Finally, research papers are grouped by specialisms with a view to exploring progress in areas such as organ transplantation, therapeutic use of natural substances, and the use of new diagnostic techniques for disease control. This book was produced during World Veterinary Year 2011, which marked the 250th anniversary of the veterinary profession. It provides a fittingly concise and enjoyable overview of the whole science of veterinary medicine.

\title{
How to reference
}

In order to correctly reference this scholarly work, feel free to copy and paste the following:

Daniel Petit, Jean-Michel Petit and François Gallet (2012). Analysis of 3'UTR of Prnp Gene in Mammals: Possible Role of Target Sequences of miRNA for TSE Sensitivity in Bovidae and Cervidae, A Bird's-Eye View of Veterinary Medicine, Dr. Carlos C. Perez-Marin (Ed.), ISBN: 978-953-51-0031-7, InTech, Available from: http://www.intechopen.com/books/a-bird-s-eye-view-of-veterinary-medicine/evolution-of-3-utr-of-prnp-genesand-sensitivity-to-prion-disease-in-mammals-

\section{INTECH}

open science | open minds

\section{InTech Europe}

University Campus STeP Ri

Slavka Krautzeka 83/A

51000 Rijeka, Croatia

Phone: +385 (51) 770447

Fax: +385 (51) 686166

www.intechopen.com

\section{InTech China}

Unit 405, Office Block, Hotel Equatorial Shanghai

No.65, Yan An Road (West), Shanghai, 200040, China 中国上海市延安西路65号上海国际贵都大饭店办公楼 405 单元

Phone: +86-21-62489820

Fax: +86-21-62489821 
(C) 2012 The Author(s). Licensee IntechOpen. This is an open access article distributed under the terms of the Creative Commons Attribution 3.0 License, which permits unrestricted use, distribution, and reproduction in any medium, provided the original work is properly cited. 